\title{
Application of Complementary Split Ring Resonator for Hyperthermia
}

\author{
Rahmawati Yusri ${ }^{1}$, Muldarisnur ${ }^{1}$ \\ ${ }^{1}$ Department of Physics, Faculty of Mathematics and Natural Sciences \\ Universitas Andalas, Padang, Indonesia
}

\begin{tabular}{|c|c|}
\hline Article Info & ABSTRACT \\
\hline Article History: & \multirow{11}{*}{$\begin{array}{l}\text { One of the most promising researches for cancer therapy with fewer side } \\
\text { effects is hyperthermia treatment using metamaterial. This treatment may stand } \\
\text { independently or adjunct to other cancer treatments such as chemotherapy, } \\
\text { radiotherapy, and others. Metamaterial may control the heating process needed } \\
\text { and also the depth of metamaterial itself from the skin surface. In this } \\
\text { simulation, complementary split-ring resonator (cSRR) metamaterial with gaps } \\
\text { from } 0.5 \text { to } 3.5 \mathrm{~mm} \text { can be used for the hyperthermia treatment. In the } \\
\text { simulation of the cSRR metamaterial as hyperthermia therapy for cancer cells, } \\
\text { the heat generated from each cSRR model was not significantly different. All } \\
\text { cSRR models can reach hyperthermal temperatures under } 5 \text { minutes. The } \\
\text { highest temperature achievement after } 60 \text { minutes can be seen in the use of } \\
\text { single gap cSRR }\left(58.9^{\circ} \mathrm{C}\right) \text {, dual gaps cSRR }\left(58.1^{\circ} \mathrm{C}\right) \text {, triple gaps cSRR }(57.5 \\
\left.{ }^{\circ} \mathrm{C}\right) \text {, and quad gaps cSRR }\left(57.2^{\circ} \mathrm{C}\right) \text {. The cSRR metamaterial structure can be } \\
\text { used for hyperthermia therapy by adjusting the treatment duration treatment on } \\
\text { cancer cells. }\end{array}$} \\
\hline Received: January 27, 2021 & \\
\hline Revised: February 10, 2021 & \\
\hline Accepted: February 16, 2021 & \\
\hline Keywords: & \\
\hline$c S R R$ & \\
\hline cancer therapy & \\
\hline hyperthermia & \\
\hline metamaterial & \\
\hline resonant frequency & \\
\hline & \\
\hline
\end{tabular}

Rahmawati Yusri

Email:

rahmawati2yusri@gmail.com

\section{INTRODUCTION}

Cancer is a disease caused by genetic instability that can change the cellular behaviour of normal cells. Changes in genetic molecules cause cells to become less sensitive to the diagnostic signals that control the cells' growth and development cycle and avoid apoptosis (Hanahan et al., 2000). Unlike cancer cells, normal cells can receive signals to regulate and integrate cell function, growth, and development.

Generally, cancer treatment aims to regulate, stop the growth, inhibit the spread, and kill cancer cells. Several cancer treatments have been developed, such as chemotherapy, radiotherapy, cryotherapy, surgery.However, existing cancer treatments so far still provide various side effects. Cinausero et al. (2017) and Mcquade et al. (2014) shows the side effects of chemotherapy, such as depression of the spinal cord, cardiotoxicity, and an increased chance of developing a second cancer due to the use of anti-tumor drugs for a long time. Radiotherapy cancer treatment employing xray or gamma ray might trigger several conditions, ranging from hyposalivation to central nervous system disturbances (Fitriatuzzakkiyah et al., 2017).

One of the most effective ways to treat cancer cells alone is with hyperthermia methods. Hyperthermia impacts the cell's protein so that the function of cell membranes changes. It causes increased cell permeability through protein denaturation and aggregation processes when the cell's temperature is above $39^{\circ} \mathrm{C}$ (Lemine, 2019). Hyperthermia was developed for cancer treatment by 
Yusri and Muldarisnur: Application of Complementary Split Ring Resonator for Hyperthermia

increasing the cancerous area temperature to $40-46^{\circ} \mathrm{C}$ and maintained for a period of time to ensure sufficient tumor damage while the healthy cells surrounding them remain at normothermi cell (Asin et al., 2012; Roti, 2008; Wu etal, 2002; Nielsen et al., 2001; Ds, 1996 ).

The hyperthermia as simultaneous therapy for metastatic tumors will pose the risk to the patient due to the physiological stress handling caused by the procedures; ideally the stress is handled effectively and swiftly (Shortetal, 1980). Heat beams penetrability is profound, it reaches layers far below the skin surface. The fact becomes a significant deliberation in hyperthermia system developed as a cancer treatment modality. In addition to its non-invasive techniques, targeted cancerous cells are generally located far below the skin surface. In fact, it is still difficult to regulate the temperature in the local area (tumor) in the living body to produce the desired temperature without affecting the surrounding cells (Szigeti et al., 2013; Ishihara et al., 2011). Measuring internal body temperature in a non-invasive and precise manner is not easy.

Metamaterials are believed to be a solution in applying hyperthermia as a modality of cancer therapy. Hyperthermia may stand independently or as an adjunct to other cancer treatments such as chemotherapy, radiotherapy, and others (Wust et al., 2002). The main challenge in hyperthermia is to produce a proper and homogeneous temperature only in the cancerous tissue, without damaging the surrounding healthy tissue by modifying the metamaterial.Since electromagnetic waves are one of the main potential methods used for non-invasive heating (Lele, 1980), the complementary Split Ring Resonator (cSRR) flat metamaterial structure is used for heat-generating applicators for hyperthermic states. cSSR is designed to work at radio frequencies 434 to $915 \mathrm{MHz}$ for surface tumor (Sheetal et al., 2016).

The cSSR structure used in this study consisted of four gaps (Maria, 2011). The cSRR design has the advantage of generating two resonant frequencies in the adjacent frequency range and easy to manufacture. Several studies using complementary Split Ring Resonator (cSRR) designs with different gap sizes have resulted in different resonant frequencies. Francisco (2010) shows that the complementary Split Ring Resonator (cSRR) produces multiple resonant frequencies between 0.5 and 3.0 GHz. Whereas Di et al. (2015) reported the resonant frequencies in the cSRR design in the 3 and 4 $\mathrm{GHz}$ range. Resonant frequencies in the range between 2.5 and $5.5 \mathrm{GHz}$ were also found by Raphael et al, (2017). Song et al. (1985) introduce that hyperthermia effect is present at mild hyperthermia (40$42^{\circ} \mathrm{C}$ ) and this enhanced response to radiotheraphy and chemotherapy.

Data obtained from the use of cSSR on hyperthermia application on cancer cells is analized numerically. Cell parameters and cSSR dimensions need to be defined before the numeric analysis.

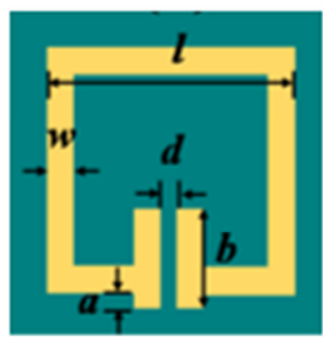

(a)

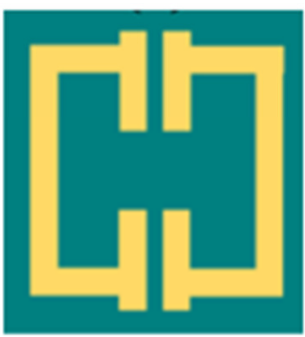

(b)

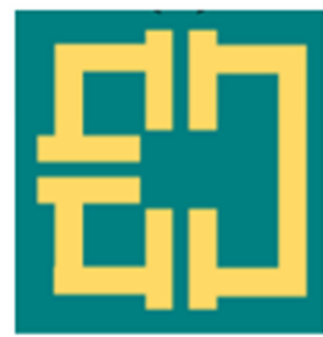

(c)

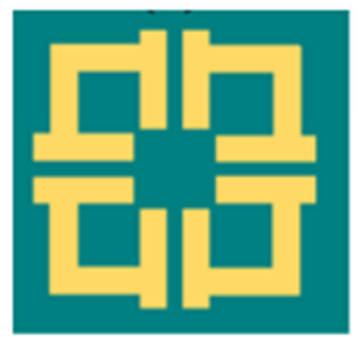

(d)

Figure 1. Design of Complementary Split Ring Resonator (cSRR) (a) single (b) dual, (c) triple, (d) quad.

Table 1. The parameters of tissues design and simulation.

\begin{tabular}{lccccc}
\hline Tissue & $\begin{array}{c}\text { Density } \\
(\mathbf{k g} / \mathbf{m} 3)\end{array}$ & $\begin{array}{c}\text { Heat Capacity at } \\
\text { constant pressure } \\
(\mathbf{J} /(\mathbf{K g} . \mathbf{K}))\end{array}$ & $\begin{array}{c}\text { Relative } \\
\text { Permeability }\end{array}$ & $\begin{array}{c}\text { Thermal } \\
\text { Conductivity } \\
\text { (W/m K) }\end{array}$ & $\begin{array}{c}\text { Electrical } \\
\text { Conductivity(S/m) }\end{array}$ \\
\hline Skin & 1109 & 3391 & 3 & 0.37 & 0.333 \\
Fat & 911 & 2348 & 4 & 0.21 & 0.333 \\
Muscle & 1090 & 3421 & 34 & 0.49 & 0.677 \\
Cancer & 1020 & 3510 & 50 & 0.5641 & 5 \\
\hline
\end{tabular}




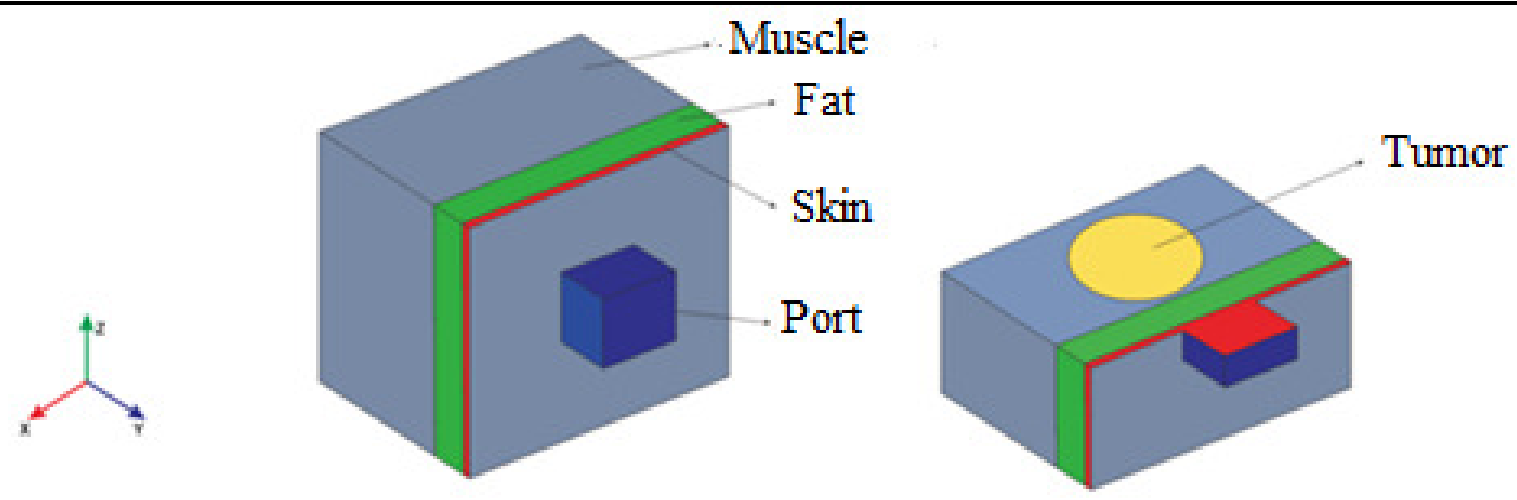

Figure 2. Hyperthermia cancer cell simulation design.

\section{METHOD}

The Finite Element Method (FEM) is used to perform finite element analysis for each physical phenomenon in this study through the Comsol Multiphysics 5.0 software. Comsol Multiphysics, which allows designing 3-dimensional (3D) products. In this study, analysis runs with 0.01 fault tolerance.

This research is conducted by predetermining the parameters (Table 1) used in the simulation models adapted to the metamaterial application as heat generator for hyperthermia. Metamaterial simulation is carried out by preparing four cSRR models based on Selvaraju et al., (2018), with variations in number and width of the gap as the metamaterial, as shown in Figure 1. To obtain the resonant frequencies of the four cSSR models play role as metamaterials for hyperthermia, a return and insertion of loss simulations are completed in the frequency range of 434 to $915 \mathrm{MHz}$

Furthermore, the cancer cell modeling and simulation are performed under the influence of the 4 cSRRs as metamaterial design to determine the effect of each cSRR on the temperature distribution on cancer cells (Figure 2); the duration of cSRR exposure is varied. The result will give a picture of the time required by each cSRR applicator model to reach the hyperthermia temperature in cancer cells. cSRR is assigned to the port (Figure 2). The output data from Comsol Multiphysics 5.0 were analyzed.

\section{RESULTS AND DISCUSSION}

\subsection{Resonant Frequency of complementary Split Ring Resonator (cSRR)}

The initial simulation was carried out to determine the return of loss due to the frequency applied to the cSRR (Figure 3). Each cSRR design produces a different resonant frequency, as shown in Figure 3. Unlike other cSRRs, the dual gaps cSRR (Figure 1b) does not produce a resonant frequency in the $434-915 \mathrm{MHz}$ range (Figure 3). In the one-gap cSRR, the resulting resonant frequency is in the range of $732-733 \mathrm{MHz}$, but the shift in resonant frequency is not visible in Figure 3a. In cSRR with triple gap, there is a resonance frequency gap in the range of 490-540 MHz with the return loss indicated by the value of $\mathrm{S} 11$ in the range 70-76 dB.

The shift in the width of the resonant frequency gap is significantly pronounced for the wider cSRR gap. The resonance frequency for the $0.5 \mathrm{~mm}$ gap is $490 \mathrm{MHz}$ with a return loss value of $76 \mathrm{~dB}$. Furthermore, the $1.0 \mathrm{~mm}$ gap has a resonance frequency of $502 \mathrm{MHz}$ with a return loss value of $74 \mathrm{~dB}$, and a $1.5 \mathrm{~mm}$ gap has a resonant frequency of $515 \mathrm{MHz}$ and the return loss of $72 \mathrm{~dB}$. A $2 \mathrm{~mm}$ gap has a resonance frequency of $523 \mathrm{MHz}$ with a return loss of $73 \mathrm{~dB}$ and a $2.5 \mathrm{~mm}$ gap has a resonance frequency of $534 \mathrm{MHz}$ with a return loss of $72 \mathrm{~dB}$. Finally, the resonance frequency for a $3 \mathrm{~mm}$ gap is $537 \mathrm{MHz}$ with a return loss at $70 \mathrm{~dB}$, and for a gap of $3.5 \mathrm{~mm}$, the resonant frequency is $540 \mathrm{MHz}$ with a return loss of $70 \mathrm{~dB}$. In a quad-gaps cSRR, the resonant frequency gap is in the range 535-590 MHz. In order, for gap widths $0.5,1.0,1.5,2.0,2.5$ and $3.0 \mathrm{~mm}$, have resonant frequencies of 535, $555,565,569,578,583,590 \mathrm{MHz}$ with values sequential return loss of 70, 70, 70, 69, 69, 69, and 69 $\mathrm{dB}$. 

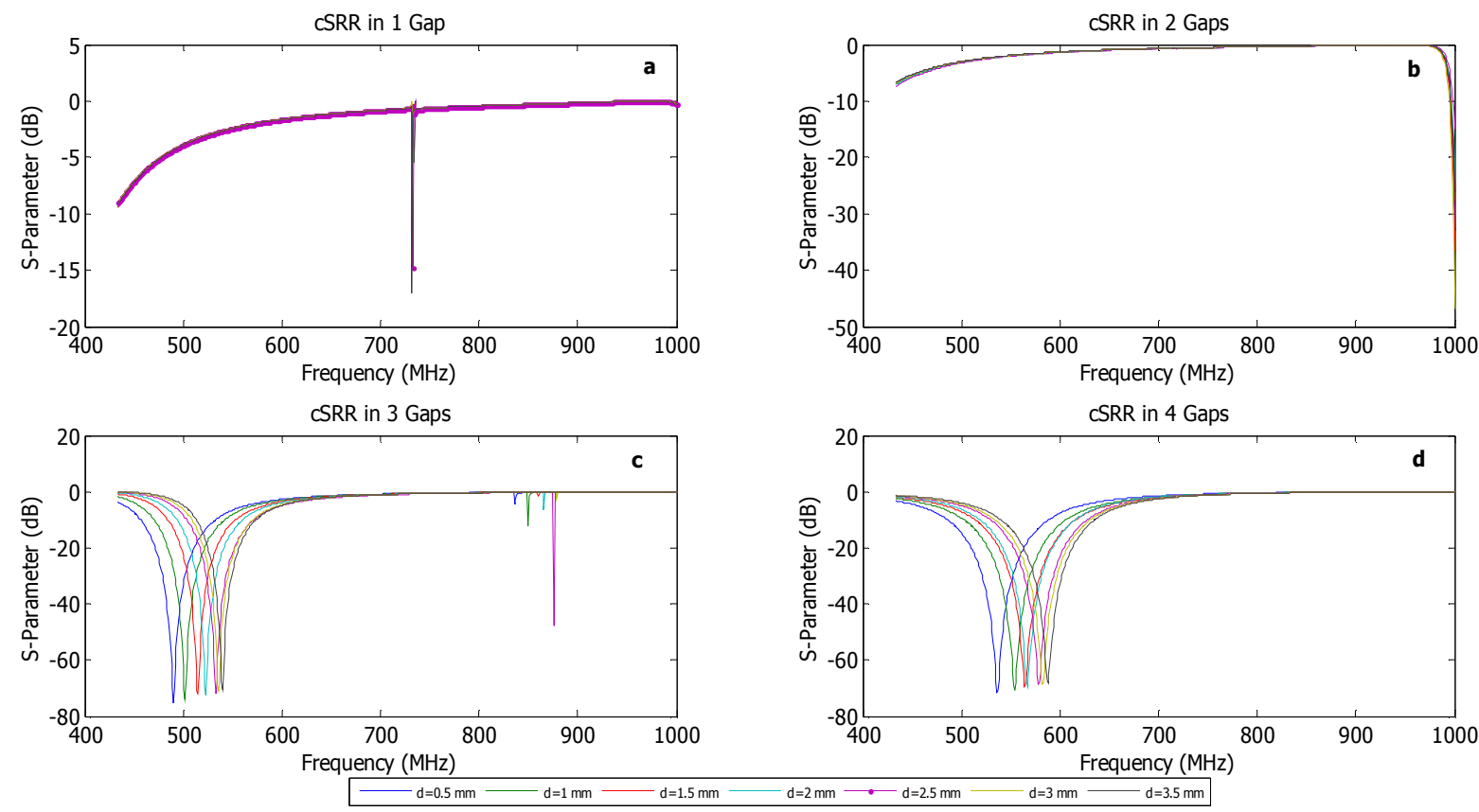

Figure 3. S11-Parameter plots of return loss simulation for every gap of cSRR structure (a) single (b) dual, (c) triple, (d) quad.
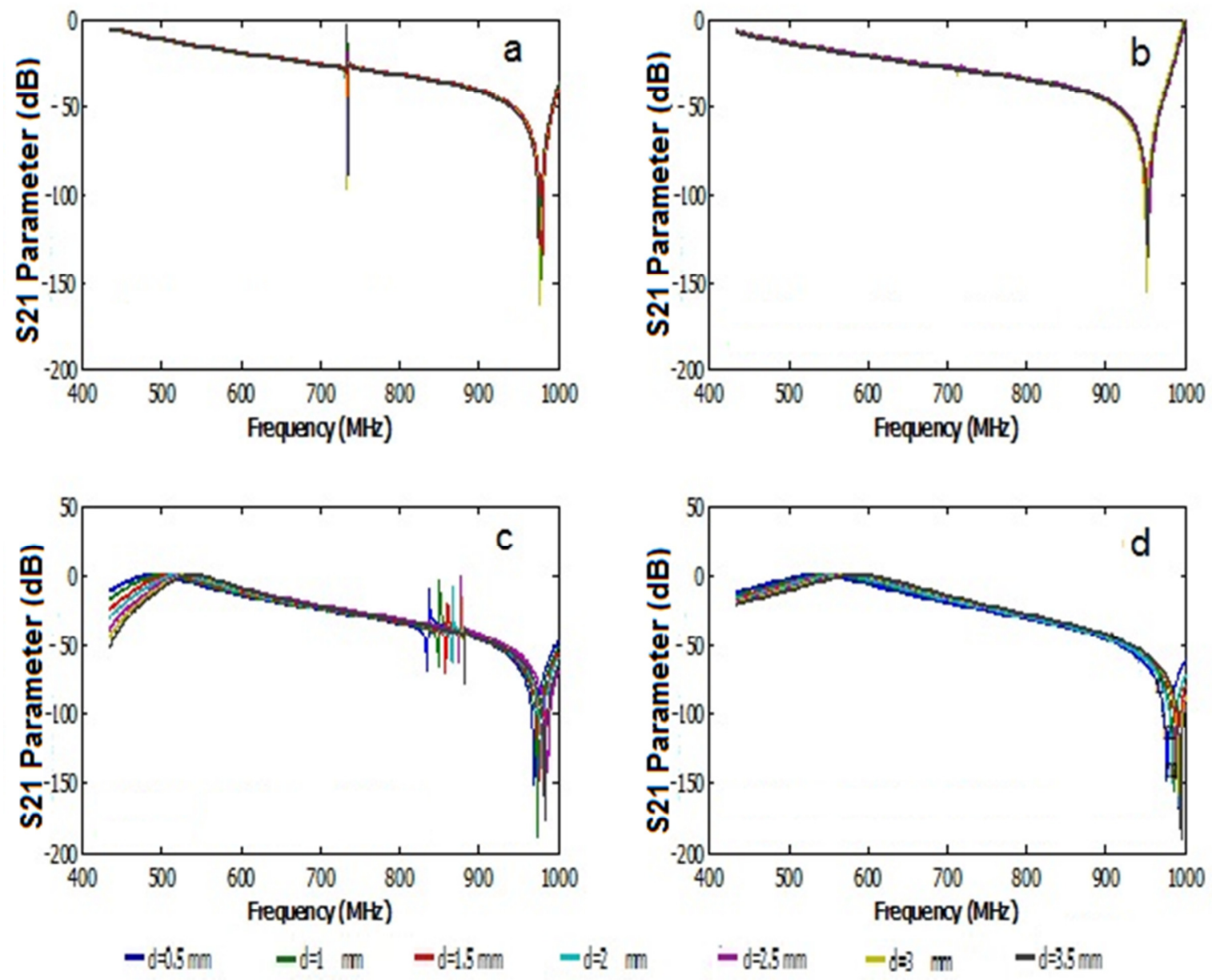

Figure 4. S21-Parameterplots of insertion loss simulation for every gap of cSRR structure (a) single (b) dual, (c) triple, (d) quad. 
In this simulation, the resulting return loss varies. In cSRR with triple and quad gaps, a clear shift in resonant frequency shows a return loss in the range of $-69 \mathrm{~dB}$ to $-76 \mathrm{~dB}$. The return loss value indicates that the power returned to the source will be small if the value is close to $0 \mathrm{~dB}$. In the S21 parameter, the single and triple gap cSRRs produce resonant frequencies in the range $434-915 \mathrm{MHz}$. Meanwhile, dual and quad gap cSRRs produce resonant frequencies outside the specified ranges. The resonant frequency in the S21 parameter is $700 \mathrm{MHz}-1000 \mathrm{MHz}$, as shown in Figure 4.

Figures 3 and Figure 4 show a shift in the resonant frequency, which corresponds to cSRR gap's width. In addition, the shift in resonant frequency is also determined by the number of gaps in each cSRR. The triple gap has two resonant frequencies in the range 800-900 MHz (Figure 4c). The first resonant frequency of cSRR with triple gaps shows that the insertion loss value is close to zero, which means that the triple gap cSRR work effectiveness is the best compared to the other three cSRR models. The smaller the insertion loss value, the more effective the cSRR will be.

\subsection{Temperature distribution in cancer cells}

The temperature distribution in cancer cells, as shown in Figure 5, is the simulation result of four cSRR models with different gap sizes. Each gap in the cSRR used in this hyperthermia simulation results in different temperature distribution. The temperature of cancer cells experienced the fastest increase when treated using single gap cSRR. After the simulation was run for 60 minutes, the temperature of the cancer cells became $58.9^{\circ} \mathrm{C}$. The temperature of cancer cells after heating for 60 minutes using cSRR for single gap, dual gap, triple gap, and quad gap were 58.9, 58.1 57.5, and 57.2 ${ }^{\circ} \mathrm{C}$.

All cSRR structures used in this simulation achieve the cell heating temperature for hyperthermia $\left(42{ }^{\circ} \mathrm{C}\right)$ in less than five minutes, with no significant time difference. Research on the treatment of hyperthermia using metamaterials has shown temperature attainment of $46^{\circ} \mathrm{C}$ through the a frequency of $4.18 \mathrm{GHz}$ (Maria, 2011). David et al. (2016) also researched on hyperthermia treatment, obtaining temperatures between $41-45^{\circ} \mathrm{C}$.

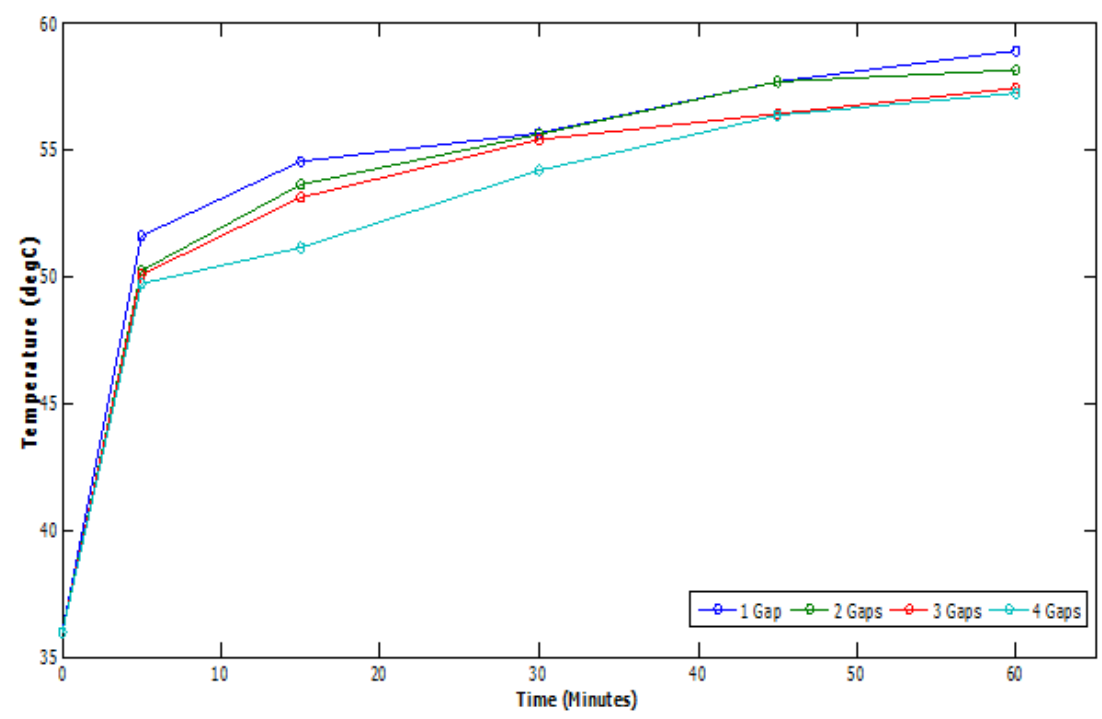

Figure 5. Simulation of cancer cell temperature distribution based on cSRR heating duration

\section{CONCLUSION}

The simulation on cSRR produces resonant frequencies in the range of 434-915 MHz. The variation in the gap width from $0.5 \mathrm{~mm}$ to $3.5 \mathrm{~mm}$ results in the resonant frequency shift from low to high. The resonant frequency shift is visible on cSRR with triple and quad gaps with an application range of 490-590 MHz. The return and insertion loss values are -70 dB for triple gaps cSRR and -69 $\mathrm{dB}$ for quad gaps cSRR. The cSRR with three gaps produces two resonant frequencies in adjacent 
Yusri and Muldarisnur: Application of Complementary Split Ring Resonator for Hyperthermia

ranges. In the simulation of cSRR as a hyperthermia therapy for cancer cells, the heat generated from each cSRR model was not significant. All cSRR models can reach hyperthermal temperatures under 5 minutes. The highest temperature achievement after 60 minutes can be seen in the use of single gap cSRR $\left(58.9^{\circ} \mathrm{C}\right)$, dual gaps cSRR $\left(58.1^{\circ} \mathrm{C}\right)$, triple gaps cSRR $\left(57.5^{\circ} \mathrm{C}\right)$, and quad gaps cSRR $\left(57.2^{\circ} \mathrm{C}\right)$. The use of cSRR for hyperthermia therapy can be done by adjusting the treatment duration on cancer cells.

\section{ACKNOWLEDGEMENT}

The author would like to thank the editorial team of the Jurnal Ilmu Fisika (JIF) and two anonymous reviewers.

\section{REFERENCE}

Asin L, Ibarra, M, R., Tres, A,. et.al., (2012). Controlled Cell Death by Magnetic Hyperthermia: Effects of Exposure Time, Field Amplitude, and Nanoparticle Concentration. Springer. 29, 5, 1319-1320.

Cinausero, M., Aprile, G., Ermacora, P, et.al., (2017). New Frontiers in the Pathobiology and Treatment of Cancer Regimen-Related Mucosal Injury.Frontiers in Pharmacology. 11, 6, 2.

David, V, Dario, B. R., Jan, V., et.al. (2016), Metamaterial Antenna Arrays for Improved Uniformity of Microwave Hyperthermia Treatments. Progress in Electromagnetic Research, 156, 1-12

Di, J., Yongmao, H., Tao, H., et.al. (2015). Implementation of A Compact Microstrip Power Divider Using Novel Split Ring Resonator., Elsevier, 126, 1782-1786.

DS, Kapp. (1996). Efficacy of adjuvant hyperthermia in the treatment of superficial recurrent breast cancer: Confirmation and future directions. Int J Radiat Oncol Biol Phys. 35, 731-744.

Fitriatuzzakiyyah, N., Sinuraya, R, K., Puspitasari, I, M.,. (2017). Terapi Kanker dengan Radiasi: Konsep Dasar Radioterapi dan Perkembangannya di Indonesia. Jurnal Farmasi Klinik Indonesia, 6, 4, 1.

Francisco, A., Adolfo V., Miguel, D-S., et.al (2010), Open Complementary Split Ring Resonators: Physics, Modelling, and Analysis. Microwave and Optical Technology Letters, 52, 7

Hanahan, D., Weinberg, R, A. (2000). The Hallmarks of Cancer, Elsevier, 100, 1.

Ishihara, Y. and Ohwad, H.(2011). Non-Invasive Temperature Measurement by Using Phase Changes in Electromagnetic Waves in a Cavity Resonator, International Journal of Hyperthermia, 27, 726-736

Junaidi, I.,(2007). Kanker-Pengenalan, Pencegahan, dan Pengobatannya.. Jakarta : PT. Bhuana Ilmu Populer.

Lele, P.P.(1980). Induction of Deep, Local Hyperthermia by Ultrasound and Electromagnetic Field, Biophys. 17, 205-217.

Lemine, O. M.(2019). Magnetic Hyperthermia Therapy Using Hybrid Magnetic Nanostructures. Hybrid Nanostructures for Cancer Theranostics, Elsevier. 125-138.

Maria, C. V., Manuel, J.F., Ricardo, M. (2011). Metamaterial Applicator for Microwave Hyperthermia, IEEE

Mcquade, R, M., Bornstein, J, C., Nurgali, K.,. (2014). Anti-Colorectal Cancer Chemotheraphy-Induced Diarrhoea: Current Treatments and Side Effects, International Journal of Clinical Medicine. 5, 393406.

Nielsen OS, Horsman M, Overgaard J. (2001). A Future for Hyperthermia in Cancer Treatment. Eur J Cancer, 37, 1587-1589.

Selvaraju, R, Jamaluddin, M, H., Kamarudin, M, R., et.al., (2018). Complementary Split Ring Resonator for Isolation Enhancement in 5g Communication Antenna Array. Semantic Scholar, 83, 217-228

Sheetal, J., Pramod, K.S., Rishabha, M., (2016). Hyperthermia: Role and Risk Factor for Cancer Treatment. Elsevier, 10, 161-167.

Short, J.G., Turner, P.F.(1980). Physical Hyperthermia and Cancer Therapy. Proc. IEEE, 68, 133-141.

Song, CW., Lokshina, A., Rhee JG., et.al. (1984). Implication of Blood Flow in Hyperthermic Treatment of Tumors, IEEE Trans Biomedic Eng, 31, 9-16.

Szigeti, G.P., Hegyi, G. and Szasz, O.(2013). Hyperthermia versus Oncothermia: Cellular Effects in Cancer Therapy. Conference of the International Clinical Hyperthermia Society : Hindawi Publishing Corporation.

Raphael, S. D., Ramasamy, P., Singaravelu, R., (2017). Design and Analysis of Open Complementary Split Ring Resonators Loaded Monopole Antenna for Multiband Operation, Progress In Electromagnetic Research C, 78, 173-182. 
Yusri and Muldarisnur: Application of Complementary Split Ring Resonator for Hyperthermia

Roti, J, L, R. (2008). Cellular Responses to Hyperthermia $\left(40-46^{\circ} \mathrm{C}\right)$ : Cell Killing and Molecular Events. International Journal of Hyperthermia, 24, 1, 1-2.

Wust, P., HIldebrandt B., Sreenivasa Y, et. al. (2002), Hyperthermia in Combined Treatment Of Cancer, Lancet Oncol, 3, 487-497. 